\title{
Из истории Владивостокской крепостной воздухоплавательной роты и Сибирского воздухоплавательного батальона (1905-1914 гг.)
}

До последнего времени история воздухоплавательных частей Владивостокской крепостной воздухоплавательной роты и Сибирского воздухоплавательного батальона была мало изучена. Рота просуществовала в общей сложности 9 лет, батальон - 3 года. Оба подразделения сыграли важную роль в истории Владивостокской крепости.

Материалы о формировании этих частей достаточно обширны. В первую очередь отметим сборник документов и материалов, изданных в 1956 г. под редакцией В.Л. Попова [10]. В нём собраны материалы, освещавшие историю воздухоплавания России с конца XIX до начала XX вв., от первых экспериментальных полетов до формирования воинских частей. Среди авторов, обращавшихся к теме истории военного воздухоплавания в России, назовём Родных А.А, популяризатора и историка науки, собравшего и систематизировавшего материалы о первых шагах воздухоплавания в России [19], Дузя П.Д. и его монографию, в которой он на основе архивных материалов в хронологическом порядке подробно осветил основные этапы зарождения и развития отечественного воздухоплавания [12]. Общими вопросами становления военного воздухоплавания в России занимались Полозов Н.П. и Сорокин М.А [18], Лашков А.Ю. и Лозыченко Ю.М. [15]. Отдельным воздухоплавательным отделениям русской армии (Брест-Литовского воздухоплавательного крепостного отделения) посвящена работа Жаркова А. и Орлова В. [13].

На сегодняшний день сведения о Владивостокской крепостной воздухоплавательной роте и Сибирском воздухоплавательном батальоне, в частности, об учениях последнего освещены в многотомной монографии коллектива авторов "Владивостокская крепость" $[1 ; 2 ; 3 ; 4]$ и в однотомном издании "Крепость Владивосток" [6]. Автор этой статьи своей задачей ставит освещение малоизученных вопросов данной темы.

Создание воздухоплавательных подразделений в конце XIX - начале XX в. проходило на опыте предыдущих поколений. Отдельные попытки использования воздушных шаров в русской армии относятся еще к первой четверти XIX в. Однако они не носили системный характер и в силу различных причин достаточно быстро прекратились. К этому вопросу вернулись в конце 60-х гг. Военно-ученый комитет в специальном постановлении 1869 г. отметил: "Во всех случаях воздушные рекогносцировки, произведенные при благоприятных обстоятельствах, могут оказать неоценимые услуги армии" [5, с. 40]. Была создана комиссия для всесторонней разработки этого вопроса, получившая название "комиссия Тотлебена" в честь ее руководителя - героя Крымской войны инженер-генерала Э.И. Тотлебена. Год спустя из отечественных материалов был построен и испытан первый русский привязной воздушный шар.

В 1884 г. в Санкт-Петербурге при Главном Инженерном управлении под руководством заведующего Гальванической (затем - Электротехнической) частью генерал-майора Борескова М.М. была создана "Комиссия по применению воздухоплавания, голубиной почты, сторожевых вышек для военных целей" [5, с. 41]. В задачу комиссии входило рассмотрение новейших открытий в аэронавтике и всех поступавших по этой части предложений; разработка вопросов по устройству в военном ведомстве кадровых станций голубиной по-

(C) Рыкунов Д. Э., 2021

РЫКУНОВ Дмитрий Эдуардович, ведущий спещиалист Российского государственного исторического архива Дальнего Востока (е. Владивосток). E-mail: dmrykunov@yandex.ru 
чты и кадровой команды воздухоплавателей с указанием способов обучения этой команды; составление соображений по дальнейшему развитию и применению воздухоплавания и голубиной почты к военным целям; рассмотрение вопросов об устройстве разного рода вышек для разведочной службы. В следующем году на основании заключения комиссии была сформирована Кадровая воздухоплавательная команда - первое регулярное военное подразделение, состоявшее из двух унтер-офицеров и двадцати нижних чинов. Руководство командой принял поручик Александр Матвеевич Кованько, в дальнейшем прославленный русский воздухоплаватель [16]. В 1887 г. численность Воздухоплавательной команды составила уже 57 человек (6 офицеров и 51 нижний чин). Подразделение занималось испытательными полетами на небольшие расстояния и высоты, производила воздушную съемку, подготовку личного состава (изучение устройства воздушных шаров, наполнение их газом, правильное обращение с газогенераторной установкой, паровой лебедкой и др.). В том же году Воздухоплавательная команда была переименована в Учебный кадровый воздухоплавательный парк, а в 1890 г. приказом № 126 по военному ведомству в Учебный воздухоплавательный парк, который впоследствии стал кузницей офицерских кадров для российских военно-воздушных сил [24].

K началу XX в. в большинстве крупных сухопутных крепостях Российской империи были сформированы воздухоплавательные отделения: Варшавское в 1891 г., два года спустя в 1893 г. - Осовецкое, Новогеоргиевское и Ивангородское. В 1895 г. было создано Ковенское крепостное воздухоплавательное отделение, а в 1901 г. - Брест-Литовское.

Согласно "Положению о специальном образовании инженерных войск" крепостные воздухоплавательные отделения обустраивали и содержали в должном состоянии наблюдательные и сигнальные станции, оснащенные привязными шарами; несли службу и поддерживали сообщения при помощи свободных шаров; обращались с приборами, предназначенными для электрического освещения в применении его к воздухоплаванию, ремонтировали воздухоплавательные шары (ПВВ № 174 от 06 июля 1896 г. Приложение. Отдел Третий).

Нижние чины в ходе учебного процесса изучали названия и назначения главнейших частей имущества воздухоплавательного отделения, а также названия и назначения главнейших частей газодобывающих приборов и их принадлежностей, занимались укладкой и переноской имущества, установкой наполненного шара на бивуак, изготовлением различного рода перевязок, узлов, петель, производили работы по продуванию и наполнению шаров газом (ПВВ № 174 от 06 июля 1896 г. Приложение. Отдел Второй). После прохождения курса обучения личный состав воздухоплавательной роты должен был уметь проводить подготовительные работы по снаряжению и использованию всей материальной части, положенной по табелю; добывать водородный газ и наполнять им оболочки шаров; поднимать и спускать привязные шары; производить походные движения с привязным шаром, а также проводить все необходимые работы по снаряжению шаров для свободных полетов; починке имущества воздухоплавательных шаров. Особые требования предъявлялись к портным - святочникам (ремонтникам). Они должны были уметь обращаться со швейными машинками, чистить их, уметь шить вручную, чинить повреждения в оболочке воздушных шаров, подготавливать сети и воздушные принадлежности, чинить и декатировать (производить влажно-тепловую обработку) веревочных снастей (ПВВ № 174 от 06 июля 1896 г. Приложение. Отдел Второй).

В начале русско-японской войны была сформирована Сибирская полевая воздухоплавательная рота с материальной частью крепостного типа, а в июне 1904 г. - первая полевая воздухоплавательная часть: 1-й Восточно-Сибирский полевой воздухоплавательный батальон 2-ротного состава. В 1905 г. был сформирован 2-й и 3-й Восточно-Сибирские полевые воздухоплавательные батальоны [8, с. 621622].

Первый в истории отечественного воздухоплавания боевой подъем привязного аэростата, состоявшийся 12 июня 1904 г. в районе деревни Гудзяцы, показал, насколько перспективным может быть использование аэростатов в армии: разведка и топографическая съемка местности, корректировка артиллерийского огня и др. "Деятельность шаров понравилась настолько, что те- 
перь не только штабы трех армий, но и штабы корпусов умоляют о высылке им шаров"[25].

Успешное боевое применение привязных аэростатов в Манчжурии оказало большое влияние на дальнейшее развитие русского военного воздухоплавания. Именно в ходе войны было принято решение о формировании Владивостокской крепостной воздухоплавательной роты. В телеграмме от 7 ноября 1904 г. Главнокомандующего Маньчжурской армии генерала от инфантерии Куропаткина А.Н. начальнику штаба Сахарову В.В., в частности, говорится: "По сформированию 2-го полевого воздухоплавательного батальона, развертывая Сибирскую воздухоплавательную роту, остается инженерное, крепостного типа имущество этой роты. Пользуясь этим, желательно теперь сформировать крепостную воздухоплавательную роту, необходимую для Владивостока, или обратить Сибирскую воздухоплавательную роту в крепостную Владивостокскую" [10, c. 777]. Это предложение было поддержано начальником Главного инженерного управления генерал-лейтенантом Вернандером А.П.: "Соображения главнокомандующего о сдормировании во Владивостоке крепостной воздухоплавательной роты, пользуясь для этого имуществом крепостного типа Сибирской роты, сходятся с соображениями генерал-инспектора по инженерной части...". В связи со значительным недокомплектом воздухоплавательных частей было предложено направить в формирующуюся роту ряд офицеров из саперных частей, служивших на Дальнем Востоке [10, c. 777$]$.

Владивостокская крепостная воздухоплавательная рота была сформирована 31 января 1905 г. согласно указу Николая II. Об этом было объявлено по военному ведомству: "Государь император в 25-й день января сего года высочайше повелеть соизволил: сформировать Владивостокскую крепостную воздухоплавательную роту согласно прилагаемому при сем штату и табели ее имущества и предоставить командиру этой роты права и обязанности командира отдельного батальона. О таковом высочайшем повелении объявляю по Военному ведомству для сведения и должного, до кого касается, исполнения" [10, с. 799]. Окончательно рота была сформирована к 16 фревраля 1905 г. и входила в состав Владивостокской крепостной саперной бригады.

Согласно штатному расписанию Владивостокская крепостная воздухоплавательная рота состояла: из штаб и обер-офицеров (7 - в мирное время, в военное - 12); классных чиновников (2 и 2 соответственно), в неё входили также младшие врачи и делопроизводители по хозяйственной части; два вольноопредялющихся, строевые чины (фельдфебели, каптенармусы, старшие и младшие унтер-офицеры, ротные барабанщики, ефрейторы и рядовые (117 и 311), нестроевые нижние чины (старшие и младшие писари, медицинские фельдшеры (старшие, младшие, ротные), старшие оружейные подмастерья, мастеровые, машинисты, обозные рядовые (20 - в мирное время, 77 - в военное). Общую численность нижних чинов планировалось довести до 137 человек в мирное время и 388 в военное [10, с. 800-801]. Для обеспечения работы роты во Владивосток отправили: инженерного имущества 3500 пудов, бензина, керосина и спирта - 3000 пудов, алюминия 15000 пудов, едкого натрия - 30000 пудов, локомобилей -2 , двуколок -32 , кухонь походных -3 , лошадей офицерских - 7 [10, с. 801].

Тогда же была установлена и форма для воздухоплавательной роты. В целом она не отличалась от формы саперных частей, но имелись и свои особенности. В первую очередь к ним относились солдатские синие рабочие рубахи особого покроя и шифровка на папахах, околышах фруражек и погонах личного состава. "Государь император в 13 день февраля 1905 г., Высочайше повелел соизволить: Владивостокской крепостной воздухоплавательной роте установить форму обмундирования по общей форме воздухоплавательных частей (ПВВ № 84 от 04 апреля 1896 г.), но с папахою по описанию, объявленному при приказе по военному ведомству 1875 г., № 24, но с шифровкою a) на эполетах и погонах и погонах нижних чинов из литер "Влд" (Владивостокская), с воздухоплавательным знаком ныне существующего образца и б) на околыше фруражек нижних чинов из литера "Влд.В" (Владивостокская воздухоплавательная) (ПСЗРИ № 25825. 1905 г, с. 117-118) ${ }^{1}$.

1 ПСЗРИ - Полное собрание законов Российской Империи 
Неоценимый опыт боевого применения воздушных шаров, полученный в компанию 1904-1905 гг., всячески пропагандировался в воинских частях и гарнизонах Российской империи. 6 мая 1905 г. в 4 часа дня во Владивостоке в здании военного собрания с докладом о практическом применении воздухоплавания выступил прославленный пионер российского военного воздухоплавания подполковник Кованько А.М. (РГИА ДВ. Ф. 28. Оп. 1. Д. 271, Л. 265) ${ }^{2}$. Послушать доклад обязали всех офицеров-воздухоплавателей крепости, были приглашены также начальники отделов обороны, начальники артиллерии и инженеры крепости, офицеры Генерального штаба, генералы, штаб и обер-офицеры военного и морского ведомства.

В русско-японскую войну 1904-1905 гг. Кованько А.М. командовал 1-м Восточно-Сибирским полевым воздухоплавательным батальоном и организовал успешное боевое применение привязных аэростатов для корректирования артиллерийского огня и наблюдения за противником. Спустя годы под его руководством будут построены первый русский дирижабль и пять отечественных самолетов. Интересно, что помимо военной службы, научной и конструкторской деятельности, Александр Матвеевич был известен в обществе как незаурядный публицист, художник, поэт, коллекционер [16].

Воздухоплавательная рота крепости Владивосток была образована не на пустом месте. $К$ моменту ее создания здесь уже наработали определенный опыт работы с аэростатами. С 1904 г. во Владивостоке уже существовал 1-й военно-морской воздухоплавательный отряд. Инициатором его создания выступил начальник Отдельного отряда крейсеров әскадры Тихого океана контр-адмирал Иессен К.П., а создателем и командиром - инженер, капитан Постников Ф.А., выпускник офицерского класса Учебного воздухоплавательного парка. Его опыт поиска с высоты затонувших военных кораблей и гражданских судов, представлявших потенциальную угрозу для судоходства, заинтересовал опытного морского офицера. 26 апреля 1904 г. Иессен К.П. поручил Постникову проектирование и изготовление аэростата для совершения пробных полетов над акваторией залива с той же целью, что и в Санкт-Петербурге, а также и для обнаружения установленных японцами мин. Сферический аэростат был спроектирован и пошит в кратчайшие сроки (к 14 мая). В его изготовлении принимали участие 15 специально откомандированных в распоряжение Постникова матросов. Аэростат получил название "Эсперо" ("Надежда"). А уже 15 мая 1904 г. капитан-инженер Постников Ф.А. был назначен командиром воздухоплавательного парка, укомплектованный 20 матросами [23, с. 49]. Пробный запуск изготовленного аэростата состоялся 25 мая 1904 г. (свободный полет). Впоследствии парк снабдили более современными и надежными змейковыми аэростатами Kite ("Бумажный змей"), приобретенными в Германии. С мая до ноября 1904 г. отряд занимался тренировками, экспериментами по производству водорода и наполнению им воздушных шаров, поиском сорванных с якоря мин, наблюдением за акваторией моря вблизи г. Владивостока. Весной 1905 г. аэростат использовали в последнем походе Владивостокского отряда крейсеров, отправившегося к берегам Японии. Во время похода, длившегося с 22 по 28 апреля 1905 г., с крейсера "Россия" неоднократно поднимали аэростат. Только 24 апреля его поднимали четырежды $[11$, c. 80]. При слегка затуманенном горизонте дальность ясной видимости с высоты 200-250 м составляла около 20 миль. В результате похода с помощью аэростатов было обнаружено несколько японских шхун, которые были захвачены и отправлены на дно. Не обошлось и без конфуза, 26 апреля, когда аэростат находился в свободном полете над крейсером, порывом ветра оборвало страховочный трос, его подняло на высоту 2000 метров, но спустя некоторое время, аэростат приводнился в 4 милях от крейсера и был подобран. В целом результатом боевого использования аэростата на фрлоте остались довольны и командующий отрядом крейсеров Иессен, и офицеры морского воздухоплавательного парка, получившие бесценный опыт. После прекращения операций Владивостокского отряда крейсеров подъем воздушных шаров стали осуществлять с транспорта "Колыма". Полеты совершались на расстояние до 200 верст на высоте до 1800 метров. Всего за год было совершенно 15 свободных полетов. 12 декабря 1905 г. воздухоплавательный парк, насчитывавший

2 РГВИА - Российский государственный военно-исторический архив. 
6 шаров ("Эсперо-1", "Эсперо-2", "Чайка", "Чайка-2", "Ястреб" и змейковый аэростат № 289), электролитическую мастерскую для производства водорода, ангар, жилые помещения, передали в военное ведомство.

Обер-офицерский состав роты укомплектовали представителями воздухоплавательных, саперных, артиллерийских частей Новогеоргиевской (штабс-капитан М.К. Шистовский), Варшавской (штабс-капитан Н.Ч. Гинейко), Брест-Литовской (штабс-капитан Я.П. Кузьмин), Ковенской (штабс-капитан П.К. Карачаев) и др. крепостей. Первым командиром Владивостокской крепостной воздухоплавательной роты был назначен подполковник А.А. Нат, переведенный на новое место службы из Московского гренадерского саперного батальона [7].

С весны 1905 г. личный состав роты осуществлял учебные полеты над крепостью и акваторией Амурского залива. 27 мая 1905 г. при выполнении очередного полета трагически погиб поручик роты В.П. Минкевич. В результате стремительного спуска аэростата корзина с офицером ударилась об воду, и воздухоплаватель утонул. Его тело искали несколько дней [17].

Воздухоплавательная рота обычно состояла из 2-3 наблюдательных станций. Наблюдательная станция имела один змейковый аэростат и один запасный аэростат с лебёдками для осуществления подъёма и спуска аэростата. Во Владивостокской крепости одна наблюдательная станция была размещена на г. Седанка, где впоследствии будет построен фоорт № 6 ("Императора Николая Александровича"). С 1907 г. здесь осуществлялись учебные запуски аэростатов с артиллерийскими наблюдателями в корзинах. В этих полетах участвовал поручик 9-й Восточно-Сибирской стрелковой артиллерийской бригады Петр Николаевич Нестеров, будущий прославленный русский летчик. Место для запусков аэростатов было выбрано неслучайно, так как с этой горы просматривались подступы к Владивостоку, побережье и акватория Амурского залива, основные транспортные коммуникации (железнодорожные и шоссейные) [6, с. 140]. Вторая наблюдательная станция располагалась на высоте 217 , где впоследствии будет построен форт № 2.

В 1910 г. в рамках общероссийской военной редрормы производится реорганизация воздухоплавательных частей русской императорской армии. Приказом по Военному ведомству из чинов Владивостокской крепостной роты и чинов 1 и 2-й Восточно-Сибирских воздухоплавательных батальонов был образован Сибирский воздухоплавательный батальон 3-х ротного состава. Батальон первоначально дислоцировался во Владивостоке. Позднее две его роты перевели в село Спасское Приморской области [14].

Боевая подготовка подразделения производилась с первых дней его существования. $К$ воздухоплавательным ротам батальона регулярно прикомандировывали офицеров из разных частей гарнизона, не взирая на должности и звания. 6 июня 1911 г. приказом по крепости было предписано начальнику штаба крепости, начальникам штабов 3-й и 9-й Сибирских стрелковых дивизий, а также инженерам Кудрявцеву и Ионову (строителям фоортов№ 1 и № 3) в срок с 15 июня по 1 июля осуществить подъемы на привязных аэростатах. С 1 июля по 30 августа выделялись по 1 офицеру всех стрелковых полков 3-й и 9-й Сибирских стрелковых дивизий, 4-х артиллерийских полков и 3 -й и 9-й Сибирских стрелковых артиллерийских бригад. Первые вводные занятия для офицеров производились на месте дислокации Сибирского воздухоплавательного батальона в Гнилом углу. С 1 августа офицеры стрелковых частей должны были производить учебные подъемы на аэростатах для изучения с высоты отделов обороны крепости, а офицеры-артиллеристы, для обучения корректировке артиллерийского огня, на своих боевых участках "...офицерам частей Русского острова - на Русском острове - на высотах 104 и 131, а офицерам полуострова Муравьева-Амурского на 217 и 142 высотах" (ГАПК. НСБ. Приказы по Владивостокской крепости и 4-му Сибирскому армейскому корпусу № 194-а от 06 июня 1911 г.).

В сентябре 1911 г. были произведены подвижные сборы с участием частей гарнизона крепости. Части были разделены на две группы: "северную" и "южную". "Северную" составили 3-я Сибирская стрелковая дивизия, 3-я Сибирская стрелковая артиллерийская бригада, 2-я батарея 4-го Сибирского мортирного артиллерийского дивизиона, 1-я саперная рота 6-го Сибирского саперного батальона, команда конных разведчиков 9-го Сибирского стрелко- 
вого полка под руководством начальника 3-й Сибирской стрелковой дивизии генерал-майора Добровольского М.М. В состав "южной" группы вошли: 9-я Сибирская стрелковая дивизия, 9-я Сибирская стрелковая артиллерийская бригада, 1-я батарея 4-го Сибирского мортирного артиллерийского дивизиона, 2-я саперная и 1-я телеграфная рота 6-го Сибирского саперного батальона, команда конных разведчиков 36-го Сибирского стрелкового полка. Руководство "южными" Сибирский воздухоплавательный батальон принял участие в сборах. Одна 1-я рота осталась на месте дислокации во Владивостоке, а две другие выдвинулись: 3-я рота в район станции Раздольное, 2-я - на станцию Угольная. Обе роты участвовали в маневрах, обеспечивая наблюдение за условным противником и приняв участие в учебных стрельбах. (ГАПК. Приказы по Владивостокской крепости и 4-му Сибирскому армейскому корпусу № 312 от 06 сентября 1911 г.).

Боевая подготовка личного состава Сибирского воздухоплавательного батальона была под неусыпным надзором командования крепости.13 октября 1911 г. комендант крепости генерал-лейтенант В.А Ирман произвел смотр по-строевому и специальному образованию батальона. Строевая подготовка подразделения в целом была отмечена положительно: "Нижние чины следовали в походной форме, без шинелей в черных фруражках; при прохождении несколько нижних чинов неправильно поворачивали голову. Ружейные приемы выполняли хорошо, при выстраивании рядов, не слышно такта, перестроения произвели хорошо, маршировали хорошо. Строевое образование батальона налажено" (ГАПК. Приказы по Владивостокской крепости и 4-му Сибирскому армейскому корпусу 413-а от 10 октября 1911 г.). Тактические занятия тоже прошли успешно. Задача по подъему аэростата в условиях наступления условного противника была выполнена без нареканий. Затем личный состав продемонстрировал свои навыки ведения штыкового боя и фризической подготовки: "...учений 1 и 3 роты проследовали для нанесения штыковых ударов по чучелам на бегу. Некоторые недостаточно громко кричали ура. Далее произвели гимнастические упражнения: вольные упражнения, с палками, упражнения на снарядах и упражнения по преодолению препятствий. Выполнили хорошо" (ГАПК. Приказы по Владивостокской крепости и 4-му Сибирскому армейскому корпусу 413-а от 10 октября 1911 г.). В завершении были проверены знания и навыки личного состава, непосредственно относящиеся к воинской специальности: "Осмотрена батальонная метеостанция. Нашел ее в отличном состоянии. Одна из лучших в округе. С помощью приборов определили направление и скорость ветра $(14,6$ м/c), почти предельная для работы аэростата. Из-за ветра пришлось отказаться от наполнения шарового и змейкового аэростатов. Был наполнен только сигнальный. Когда его подняли, один из сигналов сорвало" (ГАПК. Приказы по Владивостокской крепости и 4-му Сибирскому армейскому корпусу 413-а от 10 октября 1911 г.).

В этот же день комендант крепости, совместно с командиром Владивостокской саперной бригады С.Н Ждановым произвели проверку знаний офицеров, прикомандированных к батальону от частей войск для изучения воздухоплавательного дела. Из-за плохой погоды подъемы аэростатов не стали осуществлять, а сосредоточились на проверке знания теории. Опросили 12 офицеров. На все вопросы офицеры ответили хорошо. Хорошо ими были выполнены рекогносцировочные работы.

Необходимо отметить, что в составе обоих воздухоплавательных подразделений крепости в период с 1905-1914 гг. служило немало выдающихся личностей, будущих летчиков, прославившихся на полях сражений Первой мировой войны. Одним из первых командиров Владивостокской крепостной воздухоплавательной роты был Александр Гаврилович Соловьев. Родился в Вологде в 1867 г. После окончания Симбирского кадетского корпуса и 1-го военного Павловского училища, служил в Гродно (Виленского военного округа), в 4-м саперном батальоне. Стремительно развивавшееся военное воздухоплавание заинтересовало молодого поручика, он поступил в Учебный воздухоплавательный парк и успешно его закончил. Вся дальнейшая служба Александра Гавриловича была связана с воздухоплаванием. В 1898 г. он возглавил Ковенское крепостное воздухоплавательное отделение, а в 1906 г. был переведен в крепость Владивосток. Через два года Александр Гаврилович отбывает из 
Владивостока и возглавляет различные воздухоплавательные части: 3-й Восточно-Сибирский полевой воздухоплавательный батальон (1908), 7-ю воздухоплавательную роту (1910 г.), 4-ю Сибирскую воздухоплавательную роту (1913 г.). 30 марта 1914 г. был назначен командиром Владивостокской крепостной воздухоплавательной роты, с началом Первой мировой войны вместе с ротой уходит на фрронт. А. Г. Соловьев дослужился до должности начальника тылового воздухоплавательного парка армий Западного фрронта (был инспектором военного воздушного фрлота Минского военного округа). После революции Соловьев признал новую власть и был принят на службу. Служил в Управлении воздушного фрлота Красной армии с 1918 по1924 гг. Ушел в отставку в связи с инвалидностью. Начиная с 1918 г. неоднократно арестовывался как "социально опасный элемент". В 1935 г. особым совещанием при НКВД был осужден на 5 лет ссылки. Отбывал срок в г. Оренбург. В мае 1937 г. был повторно арестован, в октябре 1937 г. приговорен тройкой УНКВД по Оренбургской области к высшей мере наказания. Приговор был приведен в исполнение в 28 октября 1937 г. [9; 22]

Интересно сложилась жизнь легендарного летчика Российской империи Евгения Владимировича Руднева. Свою карьеру воздухоплавателя, яркого и неординарного летчика он начинал во Владивостоке. Родился Евгений Владимирович 27 августа 1887 г. в Полоцкой губернии (Царство Польское) в семье военного. После завершения учебы в Александровском кадетском корпусе А.В. Руднев поступил в Николаевское инженерное училище. По окончания его летом 1907 г. он был командирован во Владивосток в крепостную воздухоплавательную роту. В течение трех месяцев был обучающим офицером в воздухоплавательном классе роты, год (с 21 октября 1907 по 25 октября 1908 г.), заведовал метеорологической станцией. В конце 1908 г. был направлен на учебу в офицерский класс Учебного воздухоплавательного парка, где был оставлен на должности младшего офицера. 19 октября 1909 г. переведен для прохождения службы в Новогеоргиевское воздухоплавательное отделение. Затем командирован в Офицерскую школу авиации Отдела воздушного фрлота в качестве инструктора для обучения полетам на аэропланах типа "Фарман". Свое мастерство он продемонстрировал на 1-м Всероссийском празднике воздухоплавания, прошедшем в Санкт-Петербурге, на Комендантском поле с 8 сентября по 1 октября 1910 г. На празднике Руднев установил несколько всероссийских рекордов. В частности 22 сентября он поднялся с пассажиром на высоту 1300 метров [21]. С 1912 г. был введен в постоянный состав Авиационного отдела Офицерской воздухоплавательной школы в Гатчине. В августе 1914 г. учился пилотированию на знаменитом 4-х моторном бомбардировщике И.И. Сикорского "Илья Муромец", но вскоре перевелся в действующую армию, где успешно воевал на Юго-Западном фронте, возглавляя 31-й корпусной авиационный отряд. В его составе Руднев совершил 157 боевых вылетов, за боевые заслуги был награжден несколькими боевыми наградами, в частности Георгиевским оружием "за то, что, будучи в должности штабс-капитана 1 августа 1915 г., когда у противника происходила усиленная перегруппировка и переброска сил, с явной опасностью для жизни, под сильным шрапнельным огнем, произвел разведку неприятельского тыла, обнаружил подход больших сил противника и своевременно доставил добытые им ценные сведения, что дало возможность штабу армии парировать готовящий сильный удар противника" [20]. Руднев не принял советскую власть. Он воевал против нее в составе Добровольческой армии, занимал несколько достаточно важных постов в Вооруженных силах юга России (ВСЮР), связанных с авиацией. В 1920 г. эвакуировался из Крыма и перебрался во Францию. Умер в Париже в 1945 г. от туберкулеза.

30 апреля 1914 г. произошла очередная реорганизация, в результате которой Сибирский воздухоплавательный батальон был упразднен. Из него выделили Владивостокскую крепостную воздухоплавательную роту и Сибирскую воздухоплавательную роту [14]. Владивостокскую крепостную воздухоплавательную роту 21 мая 1915 г. отправили на фрронт. 14 сентября того же года ее переименовали в 21-ю воздухоплавательную роту с присвоением нового штата и приданием ей двух наблюдательных станции. Сибирскирская воздухоплавательная была расквартирована в с. Спасское Приморской области, 14 июня она была изъята из состава 1-го Сибирского армейского корпуса и 
переподчинена начальнику штаба Приамурского военного округа. Роту также отправили на фрронт и 14 сентября 1915 г. переименовали в 19-ю полевую воздухоплавательную роту [14].

Резюмируя вышеизложенное, отметим, что, несмотря на сравнительно недолгое свое существование, Владивостокская крепостная воздухоплавательная рота и Сибирский воздухоплавательный батальон оставили значительный след в истории крепости. Наличие в штате аэростатов повлияло на расширение ее оборонительных возможностей, контроль близлежащих к крепости районов, налаживание эффрективной огневой защиты с помощью воздушных набдюдателей-корректировщиков, налаживание взаимодействия различных родов войск.

Не менее важным итогом стало подготовка квалифицированных кадров: как артиллерийских наблюдателей-корректировщиков, так и воздухоплавателей - будущих летчиков.

\section{Литература}

1. Авилов Р. С., Аюшин Н. Б., Калинин В. И. Владивостокская крепость: войска, фортификация, события, люди. Часть І. "Назло надменному соседу". 1860-1905 гг. Владивосток: Дальнаука, 2013. 383 с.

2. Авилов Р. С., Аюшин Н. Б., Калинин В. И. Владивостокская крепость: войска, фортификация, события, люди. Часть II. Уроки Порт-Артура. 1906-1917 гг. Владивосток: Дальнаука, 2014. 408 с.

3. Авилов Р. С., Аюшин Н. Б., Калинин В. И. Владивостокская крепость: войска, фортификация, события, люди. Часть III. "Крепость трех измерений". Владивосток: Дальнаука, 2016.518 с.

4. Авилов Р. С., Аюшин Н. Б., Калинин В. И. Владивостокская крепость: войска, фортификация, события, люди. Часть IV. Инженеры Владивостокской крепости: счастливые люди. Владивосток: Дальнаука, 2015. 378 с.

5. Анощенко Н. Зарождение воздухоплавания в России // Грибанов С. В. Пилоты Его Величества. М.: Центрполиграф, 2007. С. 40-51.

6. Аюшин Н. Б., Калинин В. И., Воробьев С.А., Гаврилкин Н.В. Крепость Владивосток. СПб.: Изд. Остров. 2001. 264 с.

7. Владивостокская крепостная воздухоплавательная рота [Электронный реcypc]. URL: https:// www.ria1914.info/index.php (дата обращения: 12.03.2021).

8. Военная энциклопедия. СПб.: Тип. Т-ва И.Д. Сытина. 1912. Том VI. 648 с.

9. Возвращённые имена. Книги памяти России. Ленинградский мартиролог том 12 // [Электронный ресурc]. URL: http:// visz.nlr.ru/person/book/t12/19/140 (дата обращения: 11.04.2021).

10. Воздухоплавание и авиация в России до 1907 г. Сборник документов и материалов. М.: Государственное издательство оборонной промышленности. 1956. 952 с.

11. Друзинин Ю.О., Емелин А.Ю. Аэростат на фрлагмане. // Гангут. 2001. № 29. C. $78-86$.

12. Дузь П.Д. История воздухоплавания и авиации в России: период до 1914 г. М., Наука. 500 с.

13. Жарков В., Орлов А. История воздухоплавания крепости Брест-Литовск // [Электронный ресурc]. URL: http:// brestdatabase.by/library/istoriya-vozduhoplavaniyakreposti-brest-litovsk (дата обращения: 11.04.2021).

14. Историческая справка по Воздухоплавательным ротам // [Электронный реcypc]. URL: http:// antologifo.narod.ru/pages/list/histore/istPIVc.htm (дата обращения: 11.04.2021).

15. Лашков А.Ю, Лозыченко Ю.М. Зарождение военного воздухоплавания в России // Военно-исторический журнал. 2002. № 8. С.40-46.

16. Павлушенко М.И Слово о Александре Матвеевиче Кованько // [Электронный pecypc]. URL: http:// www.ballooning-rus.ru/docs/kvn.pdf (дата обращения: 11.04.2021).

17. Памяти поручика Минкевича // Дальний Восток. 1905. № 1939. С. 4.

18. Полозов Н.П, Сорокин М.А Воздухоплавание. М.: Военниздат НКО СССР, 1940. $376 \mathrm{c}$.

19. Родных А.А. История воздухоплавания и летания в России: Кн 1-2. СПб.: Типография т-ва Грамотность. 1912. 150 с.

20. Руднев Евгений Владимирович // [Электронный ресурс]. URL: https:// www. ria1914.info/index.php (дата обращения: 12.03.2021).

21. Сафраев А.Е. Всероссийский праздник воздухоплавания 1910 года. По материалам российских газет. // Военная история России XIX-XX веков. материалы X Международной военно-исторической конференции. Санкт-Петербург, 2019. Сб. научных статей. СПб.: СПбГУПТД, 2017. С. 270-287. 
22. Соловьев Александр Гаврилович // [Электронный ресурc]. URL: https:// www. ria1914.info/index.php (дата обращения: 12.03.2021).

23. Титаев А.Б. В России Постников, в Америке - Post // Записки общества изучения Амурского края. 1999. Том XXXIII. С. 47-51.

24. Учебный воздухоплавательный парк [Электронный ресурс]. URL: https:// www.ria1914.info/index.php (дата обращения: 12.03.2021).

25. Шавырин С. Из истории воздухоплавания // [Электронный ресурc]. URL: http:// www.permgaspi.ru/publikatsii/stati/iz-istorii- vozduhoplavaniya.html (дата обращения: 11.04.2021).

\section{Транслитерация по ГОСТ 7.79-2000 Система Б}

1. Avilov R. S., Ayushin N. B., Kalinin V. I. Vladivostokskaya krepost': vojska, fortifikatsiya, sobytiya, lyudi. CHast' I. "Nazlo nadmennomu sosedu". 1860-1905 gg. Vladivostok: Dal'nauka, 2013. 383 s.

2. Avilov R. S., Ayushin N. B., Kalinin V. I. Vladivostokskaya krepost': vojska, fortifikatsiya, sobytiya, lyudi. CHast' II. Uroki Port-Artura. 1906-1917 gg. Vladivostok: Dal'nauka, 2014. 408 s.

3. Avilov R. S., Ayushin N. B., Kalinin V. I. Vladivostokskaya krepost': vojska, fortifikatsiya, sobytiya, lyudi. CHast' III. "Krepost' trekh izmerenij". Vladivostok: Dal'nauka, $2016.518 \mathrm{~s}$.

4. Avilov R. S., Ayushin N. B., Kalinin V. I. Vladivostokskaya krepost': vojska, fortifikatsiya, sobytiya, lyudi. CHast' IV. Inzhenery Vladivostokskoj kreposti: schastlivye lyudi. Vladivostok: Dal'nauka, 2015. 378 s.

5. Anoshhenko N. Zarozhdenie vozdukhoplavaniya v Rossii // Gribanov S. V. Piloty Ego Velichestva. M.: TSentrpoligraf, 2007. S. 40-51.

6. Ayushin N. B., Kalinin V. I., Vorob'ev S.A., Gavrilkin N.V. Krepost' Vladivostok. SPb.: Izd. Ostrov. 2001. $264 \mathrm{~s}$.

7. Vladivostokskaya krepostnaya vozdukhoplavatel'naya rota [Ehlektronnyj resurs]. URL: https:// www.ria1914.info/index.php (data obrashheniya: 12.03.2021).

8. Voennaya ehntsiklopediya. SPb.: Tip. T-va I.D. Sytina. 1912. Tom VI. 648 s.

9. Vozvrashhyonnye imena. Knigi pamyati Rossii. Leningradskij martirolog tom 12 // [Ehlektronnyj resurs]. URL: http:// visz.nlr.ru/person/book/t12/19/140 (data obrashheniya: 11.04.2021).

10. Vozdukhoplavanie i aviatsiya v Rossii do $1907 \mathrm{~g}$. Sbornik dokumentov i materialov. M.: Gosudarstvennoe izdatel'stvo oboronnoj promyshlennosti. 1956. 952 s.

11. Druzinin YU.O., Emelin A.YU. Aehrostat na flagmane. // Gangut. 2001. № 29. S. $78-86$.

12. Duz' P.D. Istoriya vozdukhoplavaniya i aviatsii v Rossii: period do 1914 g. M., Nauka. 500 s.

13. ZHarkov V., Orlov A. Istoriya vozdukhoplavaniya kreposti Brest-Litovsk // [Ehlektronnyj resurs]. URL: http:// brestdatabase.by/library/istoriya-vozduhoplavaniya-kreposti-brest-litovsk (data obrashheniya: 11.04.2021).

14. Istoricheskaya spravka po Vozdukhoplavatel'nym rotam // [Ehlektronnyj resurs]. URL: http:// antologifo.narod.ru/pages/list/histore/istPlVc.htm (data obrashheniya: 11.04.2021).

15. Lashkov A.YU, Lozychenko YU.M. Zarozhdenie voennogo vozdukhoplavaniya v Rossii // Voenno-istoricheskij zhurnal. 2002. № 8. S.40-46.

16. Pavlushenko M.I Slovo o Aleksandre Matveeviche Kovan'ko // [Ehlektronnyj resurs]. URL: http:// www.ballooning-rus.ru/docs/kvn.pdf (data obrashheniya: 11.04.2021).

17. Pamyati poruchika Minkevicha // Dal'nij Vostok. 1905. № 1939. S. 4.

18. Polozov N.P, Sorokin M.A Vozdukhoplavanie. M.: Voennizdat NKO SSSR, 1940. 376 s.

19. Rodnykh A.A. Istoriya vozdukhoplavaniya i letaniya v Rossii: Kn 1-2. SPb.: Tipografiya t-va Gramotnost'. 1912. $150 \mathrm{~s}$.

20. Rudnev Evgenij Vladimirovich // [Ehlektronnyj resurs]. URL: https:// www. ria1914.info/index.php (data obrashheniya: 12.03.2021).

21. Safaev A.E. Vserossijskij prazdnik vozdukhoplavaniya 1910 goda. Po materialam rossijskikh gazet. // Voennaya istoriya Rossii XIX-XX vekov. materialy X Mezhdunarodnoj voenno-istoricheskoj konferentsii. Sankt-Peterburg, 2019. Sb. nauchnykh statej. SPb.: SPbGUPTD, 2017. S. 270-287.

22. Solov'ev Aleksandr Gavrilovich // [Ehlektronnyj resurs]. URL: https:// www. ria1914.info/index.php (data obrashheniya: 12.03.2021).

23. Titaev A.B. V Rossii Postnikov, v Amerike - Post // Zapiski obshhestva izucheniya Amurskogo kraya. 1999. Tom XXXIII. S. 47-51.

24. Uchebnyj vozdukhoplavatel'nyj park [Ehlektronnyj resurs]. URL: https:// www. ria1914.info/index.php (data obrashheniya: 12.03.2021). 
25. Shavyrin S. Iz istorii vozdukhoplavaniya // [Ehlektronnyj resurs]. URL: http:// www.permgaspi.ru/publikatsii/stati/iz-istorii- vozduhoplavaniya.html (data obrashheniya: 11.04.2021).

Рыкунов Д. Э. Из истории Владивостокской крепостной воздухоплавательной роты и Сибирского воздухоплавательного батальона (1905-1914 гг.).

Статья посвящена истории возникновения воздухоплавательной роты и воздухоплавательного батальона Владивостокской крепости. Автор вводит в научный оборот новые документы и рассматривает ранее малоизученный вопрос о начале воздухоплавания на Дальнем Востоке. Вопрос воздухоплавания тесно увязывается со строительством Владивостокской крепости как крупнейшего фортификационного объекта на Дальнем Востоке.

Ключевые слова: Владивостокская крепость, военное дело, воздухоплавание, Дальний Восток, Сибирский воздухоплавательньй батальон, фортифбикаиия

Rykunov D. Eh. From the history of the Vladivostok fortress aeronautical company and the Siberian aeronautical battalion (1905-1914).

The article is devoted to the emergence of aeronautical company and aeronautical battalion of the Vladivostok Fortress. The author introduces new documents to scientific turnover and considers the previously important issue of the beginning of the aid at the Far East. The question of the airplane is closely linked to the construction of the Vladivostok Fortress as the largest fortification facility in the Far East.

Key words: Vladivostok Fortress, military affairs, airplane, Far East, Siberian aeronautical battalion, fortification

Для цитирования: Рыкунов Д. Э. Из истории Владивостокской крепостной воздухоплавательной роты и Сибирского воздухоплавательного батальона (1905-1914 гг.) // Ойкумена. Регионоведческие исследования. 2021. № 2. C. 29-38. DOI: 10.24866/1998-6785/2021-2/29-38

For citation: Rykunov D. Eh. From the history of the Vladivostok fortress aeronautical company and the Siberian aeronautical battalion (1905-1914) // Ojkumena. Regional researches. 2021. № 2. P. 29-38. DOI: 10.24866/1998-6785/2021-2/29-38 